JASa (Jurnal Akuntansi, Audit dan Sistem Informasi Akuntansi)

Vol. 4 No. 3/ December 2020

ISSN 2550-0732 print / ISSN 2655-8319 online

\title{
THE INFLUENCE OF ACCOUNTING INFORMATION SYSTEM CASH SALES AND INTERNAL CONTROL OF SALES EFFECTIVENESS
}

\author{
Herlina Kustianti \\ Langlangbuana University, Indonesia \\ Herlina209@gmail.com
}

\begin{abstract}
This purpose of this research is to: (1) determine the magnitude of the effect of the cash sales accounting information system on sales effectiveness. (2) determine the magnitude of the effect of internal control on sales effectiveness. The research subject was AUTO2000 Marketing Department of Toyota, the Soekarno Hatta Bandung branch and the object of research was accounting information systems and internal control and sales effectiveness. Data collection techniques used by distributing questionnaires to 35 respondents of Toyota AUTO2000 branch of Soekarno Hatta Bandung. The data obtained were then analyzed using validity test, descriptive method descriptive method, and verification method. The results of statistical testing in the accounting information system has a significant positive effect on sales effectiveness, internal control has a significant effect on sales effectiveness.
\end{abstract}

Keywords: cash sales accounting information system, internal control, sales effectiveness.

\section{INTRODUCTION}

The business world is currently growing very rapidly in the industrial, trade and service sectors. Small companies will grow and develop into large companies with complex activities and problems. One of the company's business activities is sales, which means a place to carry out the process of producing goods or services with the aim of achieving material results, in carrying out activities in the company, it consists of functions that are interrelated with its activities and support efforts to achieve company goals. These functions include the financial function, the marketing function, and the sales function. One of the most important roles is the sales function because it is the most important part of any business activity. Sales can ensure the survival of the company because from this sale the company will get profits that can be used for the survival of the company, besides that maximum sales can be a measure of the company's success in carrying out its business activities. (Yenna Anggra Ema \& Lilis Ardini, 2014). Every company certainly has a sales target, this is the motivation of the company, especially the sales department, to continue to increase sales results so that sales targets can be achieved. There are times when carrying out sales activities that have been planned by management cannot be fully achieved or are not maximally realized. So it can be said that the company's sales have not been effective. Conversely, if the sales target can be realized optimally, the company's sales can be said to be effective. Effectiveness can be measured by comparing sales targets with sales realization. (Andhika Ariadharma, 2015). If a company uses an inadequate accounting information system, the company cannot process all transactions properly so that the resulting information cannot be trusted. If the company is not able to produce information correctly, there will be errors in making decisions. In the accounting information system, there are elements of internal control that function to oversee all economic activities that occur in the company. (Robi Maulana, 2015). A tool that serves to realize company activities, namely effective internal control. With the existence of effective internal control, the company leadership in this case the manager can 
JASa (Jurnal Akuntansi, Audit dan Sistem Informasi Akuntansi)

Vol. 4 No. 3/ December 2020

ISSN 2550-0732 print / ISSN 2655-8319 online

control the company's activities well. In addition, managers can also assure themselves that the information contained in the reports received is true and reliable. (Robi Maulana, 2015).

A requirement for companies to develop a good internal sales control system and the results can be useful as a decision making tool for company earnings and as a means of controlling company performance. With good internal sales control, it will provide useful information for leaders in determining sales policies. To produce an internal sales control system that meets company standards, good management is also needed, because every good management determines the implementation of control and supervision. If the control that is carried out by the company runs as it should be, it will suppress the deviations that occur, therefore internal control needs to be increased to neutralize so that all work and activities are carried out as planned. (Yenna Anggra Ema \& Lilis Ardini, 2014). The purpose of the authors in conducting this study are: To determine the influence of cash sales accounting information systems on sales effectiveness. This is to determine the magnitude of the influence of internal control on sales effectiveness.

Hypothesis

H1: Cash Sales Accounting Information System affects Sales Effectiveness.

H2: Internal Control affects Sales Effectiveness.

According to Mulyadi (2016) states that: "The cash sales accounting information system is a network of procedures consisting of coordinated forms, records and reports and there are system building components, namely input, model, output, technology, basis. data and control, so as to provide information about sales ". According to Anastasia Diana \& Lilis Setiawati (2011) states that: "Internal control is all organizational plans, methods, and measurements chosen by a business activity to secure its assets, check the accuracy and reliability of the business accounting data, improve operational efficiency, and supports compliance with established managerial policies. Internal Control Components. According to Mardi (2011) internal control consists of 5 components, namely: Control Environment, this control environment is the perception of individuals in the company about the importance of internal control. Company leaders must demonstrate their commitment to the implementation of strict controls and policies that are consciously and directly followed by their subordinates. This kind of atmosphere is an effective control environment applied in the company. Control Activities, control activities are a set of rules and policies that have been set and outlined for the purpose of successful control within the company. Control activities are basically in the form of controls that use an information technology-based approach and controls that use a manual approach.

Risk Assessment, the organization must carry out a risk assessment to identify, analyze and manage the risks relevant to financial reporting. Everything related to the costs and benefits of control must be carefully planned and calculated so that failure and risk can have a minimized impact. The quality of information and communication, the quality of information produced provides full support for the success of the leadership in making business decisions, the report information produced by the accounting information system helps leaders make decisions related to company operations and how financial information can be communicated quickly and accurately. Supervision, effective supervision is carried out to improve performance not to diminish company performance and achievements. The effectiveness of sales is the main activity that is important in a company, because the objectives of these activities are observation (time, energy, and costs) and the 
JASa (Jurnal Akuntansi, Audit dan Sistem Informasi Akuntansi)

Vol. 4 No. 3/ December 2020

ISSN 2550-0732 print / ISSN 2655-8319 online

achievement of company goals. Effectiveness relates to one another but does not always coincide. In an organization that implements the achievement of a high level of efficiency, it may be hampered in terms of achieving effectiveness or vice versa. Factors Affecting Effectiveness, according to Richard M Steers (1995) in Khaerul Umam (2012) there are four factors that influence effectiveness, namely: Organizational Characteristics,

Environmental Characteristics, Worker Characteristics, Management Characteristics According to David Krech, Ricard S. Ceruthef \& Egerton L. Ballachery in Sudarwan Danim (2012) reveals effectiveness indicators seen from several aspects of effectiveness criteria, as follows: Number of results that can be issued, the level of satisfaction obtained, creative products, intensity will be achieved.

\section{METHODS}

The research design used is: Descriptive Research, this study aims to describe, analyze, and then draw conclusions about the state of the object under study based on the facts contained in the company. Verification Research, this study aims to find out the relationship between three variables, namely variable $\mathrm{X} 1$, variable $\mathrm{X} 2$ and

\section{Data Collection Method Questionnaire / Questionnaire}

According to Uhar Suharsaputra (2012) states that: "The questionnaire is a research method that must be answered by respondents to state their views on a problem". The use of questionnaires as a data collection method has several advantages, including standardized questions to be asked of respondents, respondents can answer the questionnaire in their spare time, the questions asked will be thought out in advance so that the answer can be trusted compared to the verbal answer, as well as questions that are filed will be more precise and uniform. The research questionnaire was distributed to 35 respondents at the Toyota AUTO2000 branch of Soerakrno Hatta Bandung.

\section{Data analysis technique}

Descriptive analysis is one type of research whose aim is to present a complete picture of the social setting or is intended for exploration and classification of a phenomenon or social reality, by describing a number of variables relating to the problem and the unit under study between the phenomena being tested. The analysis technique in this study uses multiple linear regression analysis. One of the conditions for being able to use multiple linear regression equations is the fulfillment of the classical assumption test. After the model to be tested fulfills the classical assumptions and regression, the next step is a statistical test.

\section{RESULTS AND DISCUSSION}

The results of research on cash sales accounting information system variables, internal control and sales effectiveness obtained from research questionnaires distributed to 35 respondents at Toyota AUTO2000 branch Soerakrno Hatta Bandung. The tendency of respondents' answers to statement items that have met the validity and reliability test requirements.

Descriptive Research Results

The calculations carried out are referring to each indicator and sub-indicator in each variable. An explanation of the weight of the actual score can be seen in the following table: 
Table 1. Criteria for Percentage of Respondents' Responses

\begin{tabular}{lll}
\hline No & $\%$ Total score & Criteria \\
\hline 1 & $20.00 \%-36.00 \%$ & Not Good \\
2 & $36.01 \%-52.00 \%$ & Not Good \\
3 & $52.01 \%-68.00 \%$ & Pretty Good \\
4 & $68.01 \%-84.00 \%$ & Good \\
5 & $84.01 \%-100 \%$ & Very Good \\
\hline
\end{tabular}

Source: Umi Narimawati, 2010

The score obtained from the cash sales accounting information system variable is 1710 , while the highest possible score (ideal score) is $5 \times 12 \times 35=2010$. The score for each item $=5$, the number of statement items $=12$ and the number of respondents = 35 . Based on these results, to find out how respondents respond to indicators of cash sales accounting information systems, the following formula can be used:

$$
\begin{aligned}
& \% \text { Actual Score }=\frac{\text { Actual Score }}{\text { Actual Score }} \times 100 \\
& \% \text { Actual Score }=\frac{1710}{2010} \times 100 \\
& =81.43 \%
\end{aligned}
$$

From the results of the above calculations, it can be seen that the percentage of the score obtained is in the total score between $68.01 \%-84.00 \%$, including in the good criteria.

The score obtained from the internal control variable is 1455 , while the highest possible score (ideal score) is $5 \times 10 \times 35=$ 1750. Based on these results, to find out how respondents respond to internal control indicators, the following formula can be used

$$
\begin{aligned}
& \% \text { skor aktual }=\frac{\text { skor aktual }}{\text { skor ideal }} \times 100 \\
& \begin{aligned}
\% \text { Skor aktual } & =\frac{1455}{1750} \times 100 \\
& =83.14 \%
\end{aligned}
\end{aligned}
$$

From the results of the above calculations, it can be seen that the percentage of the score obtained is in the total score between $68.01 \%$ - 84.00\% which is included in the good criteria.

The score obtained from the sales effectiveness variable is 1047 while the highest possible score (ideal score) is $5 \times 7 \times 35=1225$. Based on these results, to find out how respondents respond to indicators of sales effectiveness, the following formula can be used:

$$
\begin{aligned}
& \% \text { Actual Score }=\frac{\text { Actual Score }}{\text { score ideal }} \times 100 \\
& \% \text { Actual Score }=\frac{1047}{1225} \times 100 \\
& =85.47 \%
\end{aligned}
$$

From the results of the above calculations, it can be seen that the percentage of the score obtained is in the total score between $84.01 \%$ - $100 \%$ which is included in the very good criteria.

\section{Verification Research Results Classic assumption test Normality test}

The normality test is used to test whether the distribution of the dependent variable for each value of certain independent variables is normally distributed or not. 
The residual normality test uses the graphical method by looking at the distribution of data on the diagonal source on the Normal PP Plot of Regression Standardized Residual and KolmogorovSmirnov charts with the help of SPSS 21. As a basis for decision making, if the data spreads around the diagonal line and follows the direction of the diagonal line, It can be concluded that the regression model complies with the normality assumption and if the significance value is $>0.05$ then the distribution of the population is normal.

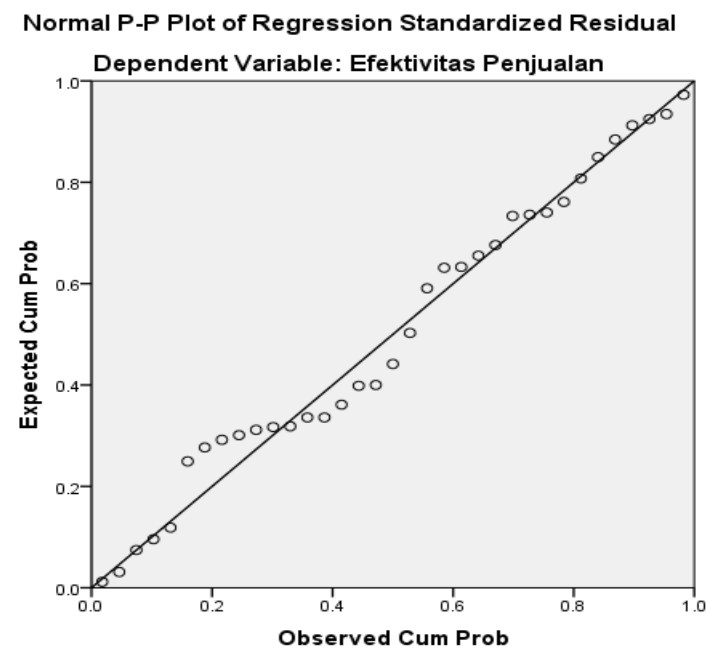

Picture 1. Normality test

Based on the normality graph using the normal p-plot above, it is known that the dots spread along the diagonal line, which indicates that the data has met the normality assumption proven by the normality results using the Komogorov-Smirnov test as follows:

Table 2. Normality Test Results

One-Sample Kolmogorov-Smirnov Test

\begin{tabular}{lll}
\hline & & $\begin{array}{l}\text { Unstandardized } \\
\text { Residual }\end{array}$ \\
\hline $\mathrm{N}$ & & 35 \\
Normal & Mean & .0000000 \\
Parametersa, & Std. Deviation & 1.99162972 \\
b & \\
Most & Absolute & .100 \\
Extreme & Positive & .089 \\
Differences & Negative & -.100 \\
Kolmogorov-Smirnov Z & .592 \\
Asymp. Sig. (2-tailed) & .875 \\
\hline a. Test distribution is Normal. & \\
b. Calculated from data. &
\end{tabular}

Source: Results of SPSS 212018 data processing

Based on the Komogorov-Smirnov test output table above, a significance value was obtained (Asymp. Sig. (2-tailed) of
0.875 . The significance value (Asymp. Sig. (2-tailed) is greater than 0.05 , so it can be 
JASa (Jurnal Akuntansi, Audit dan Sistem Informasi Akuntansi)

Vol. 4 No. 3/ December 2020

ISSN 2550-0732 print / ISSN 2655-8319 online

concluded that the data has met assumption of normality.

\section{Multicollinearity Test}

Multicollinearity test is used to test whether or not the regression model is found in the correlation between the independent variables. The guideline for a regression model that is free of multicollinearity is to have a tolerance number greater than 0.1 . The VIF limit is 10 , if the VIF value is below 10 , there are no symptoms of multicollinearity.

\begin{tabular}{|c|c|c|c|c|c|}
\hline \multicolumn{2}{|c|}{ Model } & \multicolumn{2}{|c|}{$\begin{array}{l}\text { Unstandardized } \\
\text { Coefficients }\end{array}$} & \multicolumn{2}{|c|}{ Collinearity Statistics } \\
\hline & & $B$ & Std. Error & $\begin{array}{l}\text { Tolera } \\
\text { nce }\end{array}$ & VIF \\
\hline \multirow{3}{*}{1} & (Constant) & $\begin{array}{l}7.03 \\
1\end{array}$ & 3.239 & & \\
\hline & $\begin{array}{l}\text { Cash Sales Accounting } \\
\text { Information System }\end{array}$ & .178 & .079 & .659 & 1.518 \\
\hline & Internal control & .341 & .073 & .659 & 1.518 \\
\hline
\end{tabular}

a. Dependent Variable: Sales Effectiveness

Table 3. Multicollinearity Test Results

Source: Results of SPSS 212018 data processing

Based on the output above, it is known that the two variables above have a tolerance value of more than 0.1 and a VIF of less than

\section{Heteroscedasticity Test}

The heteroscedasticity test aims to test whether in the regression model there is an inequality of variance and residuals from one observation to another.

heteroscedasticity does not occur and if the significance value is $>\quad 0.05$, heteroscedasticity does not occur.
10 , so it can be concluded that there is no multicollinearity between the independent variables.

Heteroscedasticity test using the graphic method, namely by looking at the distribution of data on the scatterplot and coefficient graphs with the help of SPSS. As a basis for decision making, if there is a clear pattern, and the dots spread above and below the zero on the $\mathrm{Y}$ axis, 
JASa (Jurnal Akuntansi, Audit dan Sistem Informasi Akuntansi)

Vol. 4 No. 3/ December 2020

ISSN 2550-0732 print / ISSN 2655-8319 online

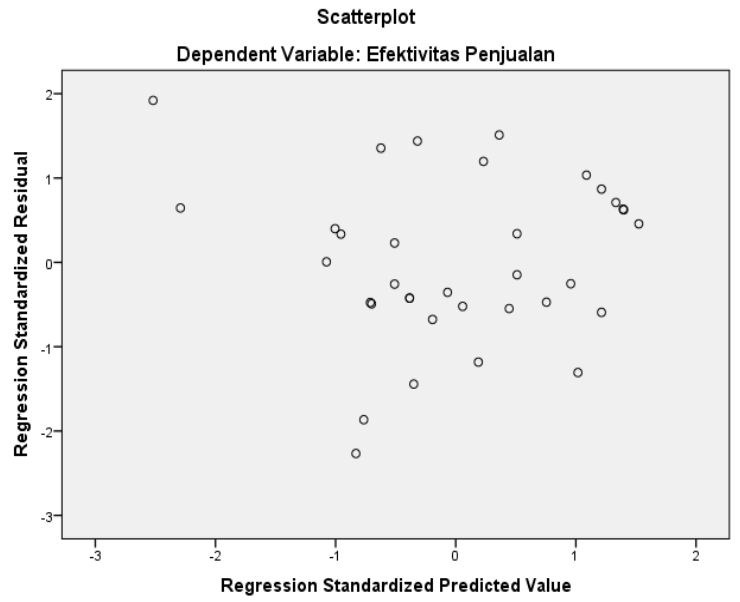

Figure 2. Heteroscedasticity Test

Based on the picture above, it is known that the points are obtained randomly and do not form a certain pattern or spread above and below the zero on the $Y$ axis, so it can be seen that the data under study does not occur heteroscedasticity as evidenced by the results of the SPSS calculation as follows:

Table 4. Heteroscedasticity Test Results

\section{Coefficients $^{a}$}

\begin{tabular}{|c|c|c|c|c|}
\hline \multirow{2}{*}{\multicolumn{2}{|c|}{ Model }} & \multicolumn{2}{|c|}{$\begin{array}{l}\text { Unstandardized } \\
\text { Coefficients }\end{array}$} & \multirow[t]{2}{*}{ Sig. } \\
\hline & & B & Std. Error & \\
\hline \multirow{3}{*}{1} & $\overline{\text { (Constant) }}$ & 3.148 & $\overline{1.814}$ & .092 \\
\hline & $\begin{array}{l}\text { Cash Sales Accounting } \\
\text { Information System }\end{array}$ & .008 & .044 & .863 \\
\hline & Internal control & -.046 & .041 & .267 \\
\hline
\end{tabular}

\section{a. Dependent Variable: RES2}

Source: Results of SPSS 212018 data processing

Based on the table above, the significance values of the two variables are 0.863 and 0.267 . The significance value is greater than 0.05 , it can be concluded that the data does not occur heteroscedasticity.

\section{Autocorrelation Test}

The autocorrelation test is used to test a model whether the confounding variables of each independent variable influence each other. To find out whether the regression model contains autocerrelation, it can be used with the D-W approach (Watson Surbin). 
JASa (Jurnal Akuntansi, Audit dan Sistem Informasi Akuntansi)

Vol. 4 No. 3/ December 2020

ISSN 2550-0732 print / ISSN 2655-8319 online

Table 5. Autocorrelation Test Results

Model Summary ${ }^{b}$

\begin{tabular}{llllll}
\hline Model & $\mathrm{R}$ & $\mathrm{R}$ & Adjusted & Std. Error of \\
& & Square & R Square & the Estimate & Watson \\
\hline 1 & $.807^{\mathrm{a}}$ & .651 & .629 & 2.05292 & 1.541
\end{tabular}

a. Predictors: (Constant), Cash Sales Accounting Information System, Internal Control,

b. Dependent Variable: Sales Effectiveness

Source: Results of SPSS 212018 data processing

Based on the table above, it is known that the $d w$ value is 1.541 . This value will be compared with the $\mathrm{dl}$ and du values in the Durbin Watson table. With $\alpha=0.05$, the number of independent variables $(K)=2$ and sample $(n)$ as many as 35 , the dl value was 1.343 and du was 1.584 , so that the $4-\mathrm{dl}$ value was 2.657 and 4 -du was 2.416 . From the above values, it is known that the value of $\mathrm{dw}(1.541)$ is between the values of $\mathrm{dl}$ (1.343) and du (1.584), which indicates that there is no certainty or definite conclusion.

Multiple Linear Regression Analysis

Multiple linear regression analysis is used to determine the linear relationship which has at least two independent variables with one dependent variable.

\section{Coefficients $^{\mathrm{a}}$}

Table 6. Multiple Linear Regression Coefficient

\begin{tabular}{|c|c|c|c|c|}
\hline \multirow{2}{*}{\multicolumn{2}{|c|}{ Model }} & & \multicolumn{2}{|c|}{ Unstandardized Coefficients } \\
\hline & & & B & Std. Error \\
\hline \multirow{3}{*}{1} & (Constant) & & 7.031 & 3.239 \\
\hline & $\begin{array}{l}\text { Cash Sales } \\
\text { Information System }\end{array}$ & Accounting & 178 & .079 \\
\hline & Internal control & & .341 & .073 \\
\hline
\end{tabular}

a. Dependent Variable: Sales Effectiveness

Source: Results of SPSS 212018 data processing

Based on the results of the SPSS 21 output above, it can be seen that the regression coefficients value is on the value of Unstandardized Coefficients "B", so that the multiple linear regression equation is obtained as follows:

$$
Y=7,031+0.178 X \_1+0.341 X \_2
$$

From the results of the multiple linear regression equation, each variable can be interpreted as follows: The constant value is 7,031 ; It can be interpreted that if the value of the cash sales accounting information system and internal control is 0 , then the effectiveness of sales is 7,031. The regression coefficient value of the cash sales accounting information system variable (b_1) is positive, namely 0.178 ; This means that each increase in the cash sales accounting information system of 1 unit will increase the effectiveness of sales by 0.178 units, assuming other independent variables have a fixed value. The regression coefficient value of internal control variable (b_2) is positive, namely 0.341 ; This means that each increase in internal control by 1 unit, it will increase the effectiveness of sales by 0.341 units, assuming other independent variables have a fixed value. 
JASa (Jurnal Akuntansi, Audit dan Sistem Informasi Akuntansi)

Vol. 4 No. 3/ December 2020

ISSN 2550-0732 print / ISSN 2655-8319 online

\section{Correlation Analysis}

Correlation analysis is used to find the closeness of the relationship and prove the relationship and variable hypothesis if the data for the two variables are normally distributed.

Table 7. Correlation Coefficient between Effect of Cash Sales Accounting Information System on Sales Effectiveness

\section{Correlations}

Cash Sales Accounting Sales Effectiveness Information System

\begin{tabular}{llll}
\hline Cash Sales & Pearson Correlation & 1 & $.643^{* *}$ \\
Accounting & Sig. (2-tailed) & & .000 \\
Information & $\mathrm{N}$ & 35 & 35 \\
System & Pearson Correlation & $.643^{* *}$ & 1 \\
Sales & Sig. (2-tailed) & .000 & \\
Effectiveness & $\mathrm{N}$ & 35 & 35 \\
\hline
\end{tabular}

Source: Results of SPSS 212018 data processing

Based on the results of the calculation of SPSS 21, it can be seen that the large correlation between the influence of the cash sales accounting information system on sales effectiveness is 0.643 . The value of 0.643 according to Sugiyono (2010: $6)$ is in the coefficient interval 0.60-0.799 including the level of a strong relationship.

Table 8. Correlation Coefficient between Effect of Internal Control on Sales Effectiveness

\begin{tabular}{llll}
\hline & & $\begin{array}{l}\text { Internal } \\
\text { Control }\end{array}$ & Sales Effectiveness \\
\hline \multirow{2}{*}{ Internal } & Pearson & 1 & $.772^{* *}$ \\
Control & Correlation & & .000 \\
& Sig. (2-tailed) & & 35 \\
& $\mathrm{~N}$ & 35 & 1 \\
Sales & Pearson & $.772^{* *}$ & \\
Effectiveness & Correlation & & \\
& Sig. (2-tailed) & .000 & 35 \\
\hline
\end{tabular}

Source: Results of SPSS 212018 data processing

Based on the results of the calculation of SPSS 21 , it can be seen that the correlation between the influence of internal control on sales effectiveness is 0.772 . The value of 0.722 according to Hypothesis testing Partial Hypothesis Testing (T Test) 
JASa (Jurnal Akuntansi, Audit dan Sistem Informasi Akuntansi)

Vol. 4 No. 3/ December 2020

ISSN 2550-0732 print / ISSN 2655-8319 online

This $T$ test aims to test how partially

the independent variables influence the dependent variable.

Table 9. Result of Partial Hypothesis Testing (T Test)

Coefficients $^{a}$

\begin{tabular}{|c|c|c|c|}
\hline & & $\mathrm{T}$ & Sig. \\
\hline 1 & $\begin{array}{l}\text { (Constant) } \\
\text { Cash Sales } \\
\text { Accounting } \\
\text { Information System } \\
\text { Internal } \\
\text { Control }\end{array}$ & $\begin{array}{l}2.171 \\
2.262 \\
4.678\end{array}$ & $\begin{array}{l}.037 \\
.031 \\
.000\end{array}$ \\
\hline
\end{tabular}

a. Dependent Variable: Sales Effectiveness

Based on table 9, the t_hitung value for the internal control variable on sales effectiveness is 4,678 and the Sig value is 0,000 . Because the value of $t$ count is greater than t table $(4,678>2,035)$ and a significance value of $0.000<0.05, \mathrm{H} \_0$ is rejected, meaning that internal control has a significant effect on sales effectiveness.

Discussion

\section{Effect of Cash Sales Accounting Information System on Sales Effectiveness}

Based on research conducted at Toyota AUTO2000, states that cash sales accounting information systems affect sales effectiveness. This can be seen from the regression coefficient value of the cash sales accounting information system variable (b_1) is positive, namely 0.178 with a significance of 0.031 , so the cash sales accounting information system has a positive effect on sales effectiveness. Based on the formulation of the problem, the magnitude of the influence of the cash sales accounting information system on the effectiveness of sales is $41.3 \%$, it can be seen from the calculation of the coefficient of determination. In addition, the large correlation between the effect of cash sales accounting information systems on sales effectiveness is 0.643 . The value of 0.643 according to Sugiyono (2010: 6) is in the coefficient interval $0.60-0.799$ including the level of a strong relationship. This is in line with research by Feto and Yos (2010) which explains that the cash sales accounting information system at PT. Gendish Mitra Kinarya implemented by the company is sufficient. According to David HM. Hasibuan (2013) states that the overall sales cycle of Novotel hotels is considered quite good. According to Moch. Nurdin Ismail and Dudi Pratomo (2012) state that the implementation of the sales accounting information system at PT.Inti (Persero) Bandung as a whole is in the very high category with a calculation result of $91.44 \%$ which means that the respondent is adequate and can support the job very well.

\section{Effect of Internal Control on Sales Effectiveness}

Based on research conducted at Toyota AUTO2000, states that internal control affects sales effectiveness. This can be seen from the regression coefficient value of the internal control variable (b_2) is positive, namely 0.341 with a significance of 0.000 , so internal control has a positive effect on sales effectiveness. The results of this study are in line with Yenna Anggra Ema and Lilis Ardini (2014), showing that the effect of 
JASa (Jurnal Akuntansi, Audit dan Sistem Informasi Akuntansi)

Vol. 4 No. 3/ December 2020

ISSN 2550-0732 print / ISSN 2655-8319 online

internal control consisting of control environment, risk assessment, information and communication, control activities and joint supervision of sales effectiveness is significant. Based on the formulation of the problem, the magnitude of the influence of internal control on sales effectiveness is $59.5 \%$, it can be seen from the calculation of the coefficient of determination. This is in line with Andhika Ariadharma's research (2015), the results show the influence of the sales internal control system at PT. Inti (Persero) Bandung. It can be seen that the correlation between the effect of internal control on sales effectiveness is 0.772 . The value of 0.722 according to Sugiyono (2010: 6 ) is in the coefficient interval of $0.60-0.799$ including the level of a strong relationship.

\section{CONCLUSION}

Based on the results of research and discussion in the previous chapter, the authors draw the following conclusions: Cash sales accounting information systems affect sales effectiveness. Sales effectiveness has not been effective because the procedures and functions used have not been operated optimally. Internal control affects sales effectiveness. Sales effectiveness is not yet effective because the control environment, control activities, risk assessment, information and communication quality, and supervision are not yet running perfectly.

\section{REFERENCES}

Ariadharma, Andhika. (2015). Pengaruh Sistem Pengendalian Internal Penjualan terhadap Efektivitas Penjualan PT. Inti Bandung. Jurnal Riset kauntansi \& Keuangan: Volume 11 No 1 Tahun 2015.

Danim, Sudarwan. (2012). Motivasi Kepemimpinan \& Efektivitas Kelompok: Rineka Cipta.

Diana, Anastasia \& Setiawati, Lilis. (2011). Sistem Informasi Akuntansi. Yogyakarta: Andi Offset.
Ema, Yenna Anggra \& Ardini, Lilis. (2014). Pengaruh Pengendalian Internal terhadap Efektivitas Penjualan pada PT. Harja Sukses Makmur. Jurnal IImu \& Riset Akuntansi:Volume 3 No 3 Tahun 2014.

Fauzi Rizki, Ahmad. (2017). Sistem Informasi Akuntansi (Berbasis Akuntansi). Yogyakarta: Deepublish.

Feto \& Yos. (2010). Analisis untuk Meningkatkan Pengendalian Internal PT. Gendish Mitra Kinarya.

Handoko, T. Hani. (2016). Manajemen Personalia dan Sumber Daya Manusia. Yogyakarta: BPFE.

Hasibuan, David HM \& Supardji. (2012). Analisa Sistem Pengendalian Penjualan dan Pengaruhnya terhadap Efektivitas Penjualan pada Pabrik Tapioka "Setia". Jurnal Ilmiah Ranggagading: Volume 12 No 2 Tahun 2012.

Hasibuan, David HM. (2013). Evaluasi Sistem Informasi Akuntansi Penjualan \& Kaitannya dengan Efektivitas Pengendalian Internal pada Hotel Novotel. Jurnal IImiah Akuntansi Kesatuan: Volume 1 No 1 Tahun 2016. ISSN: 2337-7852.

Ismail, Moc. Nurdin \& Pratomo, Dudi. (2012). Pengaruh Penerapan Sistem Informasi Akuntansi Penjualan terhadap Efektivitas Pengendalian Internal Penjualan PT. Inti (Persero).

Mardi. (2011). Sistem Informasi Akuntansi. Bogor: Ghalia Indonesia.

Maulana, Robi. (2015). Pengaruh Sistem Informasi Akuntansi terhadap Efektivitas Pengendalian Internal Penjualan pada PT. Arta Cemerlang Cabang Majalengka.

Mulyadi. (2016). Sistem Akuntansi. Jakarta: Salemba Empat.

Narimawati, Umi. (2010). Penulisan Karya IImiah. Jakarta: Penerbit Genesis.

Nazir, Moh. (2014). Metode Penelitian. Bogor: Ghalia Indonesia. 
JASa (Jurnal Akuntansi, Audit dan Sistem Informasi Akuntansi)

Vol. 4 No. 3/ December 2020

ISSN 2550-0732 print / ISSN 2655-8319 online

Priyanto, Duwi. (2012). Cara Kilat Belajar Analisis Data dengan SPSS 20 Edisi

Umam, Khaerul. (2012). Manajemen kesatu. Yogyakarta: ANDI.

Puspitawati, Lilis \& Anggadini, Sri Dewi. (2011). Sistem Informasi Akuntansi. Yogyakarta: Graha IImu.

Samryn, L. M.. (2012). Pengantar Akuntansi. Jakarta: PT RajaGrafindo Persada.

Santoso, Singgih. (2012). Panduan Lengkao SPSS versi 20. Jakarta: PT. Elex Media Komputindo.

Sedarmayanti. (2011). Manajemen Sumber Daya Manusia, Reformasi Birokasi dan Manajemen Pegawai Negeri Sipil (Cetakan kelima). Bandung: PT Refika Aditama

Simanjuntak, John Peris. dkk. (2017). Sistem Informasi Akuntansi dalam Mendukung Efektivitas Pengendalian Internal Penjualan \& Pengendalian Piutang pada PT. Post Indonesia (Persero) Regional $V$. e-Proceeding of Management: Volume 7 No 1 Tahun 2917. ISSN: 2355-9357.

Suharsaputra, Uhar. (2012). Metode Penelitian Kuantitatif, Kualitatif dan Tindakan. Bandung: PT. Refika Aditama.

Susanto, Azhar. (2013). Sistem Informasi Akuntansi. Bandung: Lingga Jaya.

Suwardjo. (2010). Teori Akuntansi: Pengungkapan dan Sarana Interpretatif Edisi Ketiga. Yogyakarta: BPFE.

Swastha, Basu \& Handoko, Hani. (2011). Manajemen Pemasaran-Analisis Perilaku Konsumen. Yogyakarta: BPFE.

TMbooks. (20150. Sistem Informasi Akuntansi Konsep dan Penerapan. Yogyakarta: C.V Andi offset.

Triandi \& Siregar, Jahja Diapari. (2007). Evaluasi Sistem Pengendalian Internal Penjualan terhadap Peningkatan Efektivitas Penjualan Kamar Hotel Horison Bekasi. Jurnal IImiah Ranggagading: Volume 7 No 2 Tahun 2007. 